\title{
Revisiting horseshoe crab fossils from the Middle Triassic (Anisian) Strelovec Formation Konservat-Lagerstätte of Slovenia
}

\author{
Russell D.C. Bicknell, Jure Žalohar, Primož Miklavc, \\ Bogomir Celarc, Matija Križnar, and Tomaž Hitij
}

\begin{abstract}
Xiphosura are a group of marine euchelicerates with a fossil record spanning the majority of the Phanerozoic. Despite this longevity, horseshoe crab fossils are uncommon. This rarity is a result of their cuticular exoskeleton that limits the preservational potential of xiphosurid specimens. Nonetheless, a xiphosurid evolutionary radiation is recorded in Triassic-aged deposits. This event likely reflects the occupation of vacant niches after the end-Permian extinction. Here, we revisit Sloveniolimulus rudkini Bicknell et al., 2019b—a Middle Triassic horseshoe crab from the Strelovec Formation that was previously known from one specimen-and include newly identified material to explore the validity of the taxon. We demonstrate that unique genal spine morphologies are observed in all specimens, supporting the maintenance of S. rudkini. In documenting this material, we also considered the preservational pathways for horseshoe crabs in limestone and document other metazoan groups from this as-of-yet underexplored Konservat-Lagerstätte.
\end{abstract}

Russell D.C. Bicknell. Palaeoscience Research Centre, School of Environmental and Rural Science, University of New England, Armidale, 2351, Australia. Corresponding author rdcbicknell@gmail.com Jure Žalohar. T-TECTO, Koroška cesta 12, SI-4000 Kranj, Slovenia. jure.zalohar@guest.arnes.si Primož Miklavc. Department of Geology, Faculty of Natural Sciences and Engineering, University of Ljubljana, Aškerčeva ceta 12, SI-1000 Ljubljana, Slovenia. primoz.miklavc@gmail.com Bogomir Celarc. Geological Survey of Slovenia, Dimičeva ulica 14, SI-1000 Ljubljana, Slovenia. Matija Križnar. Slovenian Museum of Natural History, Prešernova 20, SI-1000 Ljubljana, Slovenia. mkriznar@pms-lj.si

Tomaž Hitij. Dental School, Faculty of Medicine, University of Ljubljana, Hrvatski trg 6, SI-1000 Ljubljana, Slovenia. tomazhitij@gmail.com

Keywords: Triassic; Xiphosurida; Sloveniolimulus; Slovenia; Strelovec Formation; exceptional preservation Submission: 23 May 2021. Acceptance: 24 November 2021.

Bicknell, Russell D.C., Žalohar, Jure, Miklavc, Primož, Celarc, Bogomir, Križnar, Matija, and Hitij, Tomaž. 2021. Revisiting horseshoe crab fossils from the Middle Triassic (Anisian) Strelovec Formation Konservat-Lagerstätte of Slovenia. Palaeontologia Electronica, 24(3):a36. https://doi.org/10.26879/1168

palaeo-electronica.org/content/2021/3480-on-sloveniolimulus-rudkini

Copyright: December 2021 Palaeontological Association.

This is an open access article distributed under the terms of Attribution-NonCommercial-ShareAlike 4.0 International (CC BY-NC-SA 4.0), which permits users to copy and redistribute the material in any medium or format, provided it is not used for commercial purposes and the original author and source are credited, with indications if any changes are made.

creativecommons.org/licenses/by-nc-sa/4.0/ 


\section{INTRODUCTION}

Horseshoe crabs (Xiphosura) are a euchelicerate group with an extensive fossil record ranging from the Lower Ordovician through to today (Van Roy et al., 2010, 2015; Bicknell and Pates, 2020). The group has experienced two major evolutionary events across this time: the Pennsylvanian belinurid diversification and the Triassic austrolimulid and limulid radiation (Raymond, 1944; Bicknell et al., 2019b, 2021b; Lustri et al., 2021). The Triassic radiation is particularly interesting as the forms that arose after the end-Permian represent some extreme limits of the horseshoe crab Bauplan (Riek, 1955; Pickett, 1984; Lerner et al., 2017). Due to these unique morphologies, Triassic-aged horseshoe crabs have recently been a focal point in research considering Xiphosurida, an order within Xiphosura (Lamsdell, 2016; Lerner et al., 2017; Bicknell et al., 2019b, 2021a). Among the array of Triassic taxa, Sloveniolimulus rudkini Bicknell et al., 2019b from the Strelovec Formation (Middle Triassic, Anisian) of Slovenia has been discussed. Lamsdell (2020) suggested that, based on preservation, the taxon should be considered a nomum dubium. Conversely, Bicknell et al. (2021a) supported the position of the taxon within Limulidae. The perspective of Lamsdell (2020) is worth considering, especially as more material would be informative for presenting a thorough documentation of the genus. We therefore revisit $S$. rudkini by examining two new specimens from the Strelovec Formation. We also discuss the depositional environment and palaeobiodiversity preserved within the Strelovec Formation.

\section{GEOLOGICAL CONTEXT}

The Strelovec Formation is exposed across the Kamnik-Savinja Alps (Celarc, 2004; Hitij et al., 2010; Celarc et al., 2013) and partly along the Julian Alps (Hitij et al., 2010; Žalohar and Hitij, 2013; Kadivec, 2020; Figure 1A-C). The formation is located stratigraphically above the Upper Sarl Dolomite and overlain by the shallow-water Contrin Formation (Celarc et al., 2013; Figure 1D). The stratigraphic position (Celarc et al., 2013) and similarity with the Chinese Panxian and Luoping faunas (Tintori et al., 2014) suggests that the Strelovec Formation is Pelsonian to early Illyrian in age. The thickness and expression of Strelovec Formation lithostratigraphic units differ between outcrops and even within exposed sections, reflecting differential depositional rates within the basin. Despite this variation, the formation is $\sim 150 \mathrm{~m}$ thick and characterised by successive dark, laminated, bituminous limestones, brown to bright yellow, thinto thick-bedded limestones and dolomites, and green thin-bedded limestones (Celarc, 2004). These laminated sediments excellently preserve articulated fossils and are indicative of an anoxic marine palaeoenvironment (Hitij et al., 2010).

During the Middle Triassic, the modern-day Kamnik-Savinja Alps were located on the southwestern Neotethyan embayment at the opening of the Meliata-Maliac Ocean, at about the equator (Stampfli et al., 2002; Schmid et al., 2008). The predominance of thinly bedded, horizontal laminated mudstones, presence of organic matter, and the absence of shallow-water elements within the Strelovec Formation suggest hemipelagic and pelagic sedimentation in a hydrodynamically quiet marine environment (Miklavc et al., 2016). Synsedimentary structures (slump-folds, micro-faults, and resedimented blocks) are common, indicating an inclined depositional environment and/or subsidence during deposition (Žalohar and Hitij, 2010; Miklavc et al., 2016). Furthermore, celestine crystals are common within the laminated bituminous limestones, indicating seawater evaporation (Žalohar and Hitij, 2010; Bicknell et al., 2019b).

Based on the sedimentological, palaeontological, mineralogical, and geographical data, the Strelovec Formation was likely deposited in an isolated, deep, equatorially-located, intraplatform basin that was several tens of kilometres wide. This environment would have limited access to the open ocean. High equatorial temperatures would have accelerated the evaporation rate within the basin and surrounding carbonate platforms. This rapid evaporation likely produced a dense anoxic brine that would have flowed into the deepest sections of the basin, resulting in a hypersaline environment that permitted the development of microbial mats that likely covered the basinal sediment. Microbial mats, coupled with a relatively high sedimentation rate, increased subaerial volcanism (Haas et al., 1995), a hydrodynamically quiet marine environment (Miklavc et al., 2016), and hypoxia and/or anoxia at the basin bottom produced ideal conditions for the observed KonservatLagerstätte-type preservation. As a result, algal, plant, mollusc (gastropods, bivalves, and ammonoids), echinoderm (crinoids, echinoids, and ophiuroids), lingulate and articulate brachiopods, euarthropods (decapods, thylacocephalans, and xiphosurids), and vertebrate (fishes and reptiles) remains have been exceptionally preserved within the Strelovec Formation. 


\section{METHODS}

The assessed material was collected from two outcrops of the Strelovec Formation in the KamnikSavinja Alps (Figure 1). The holotype was collected on the northern slopes of the Križevnik Mountain (1909 m above sea level) in the Robanov Kot Valley (Bicknell et al., 2019b). The two new specimens were collected on the western slopes of the Kalška gora Mountain (2058 m above sea level) in the Kamniška Bistrica Valley (Figure 1C). Horseshoe crab specimens are preserved as flat- tened or slightly domed impressions in limestone. Specimens were coated in ammonium chloride sublimate and photographed under normal LED light with a Canon EOS 5DS. Images were stacked using Helicon Focus 7 (Helicon Soft Limited) stacking software. Measurements were obtained from photographs using ImageJ. All specimens are housed within the Hitij and Žalohar Paleontological Collection, curated, and registered according to Slovenian legislation, within the Slovenian Museum of Natural History, Ljubljana, Slovenia.
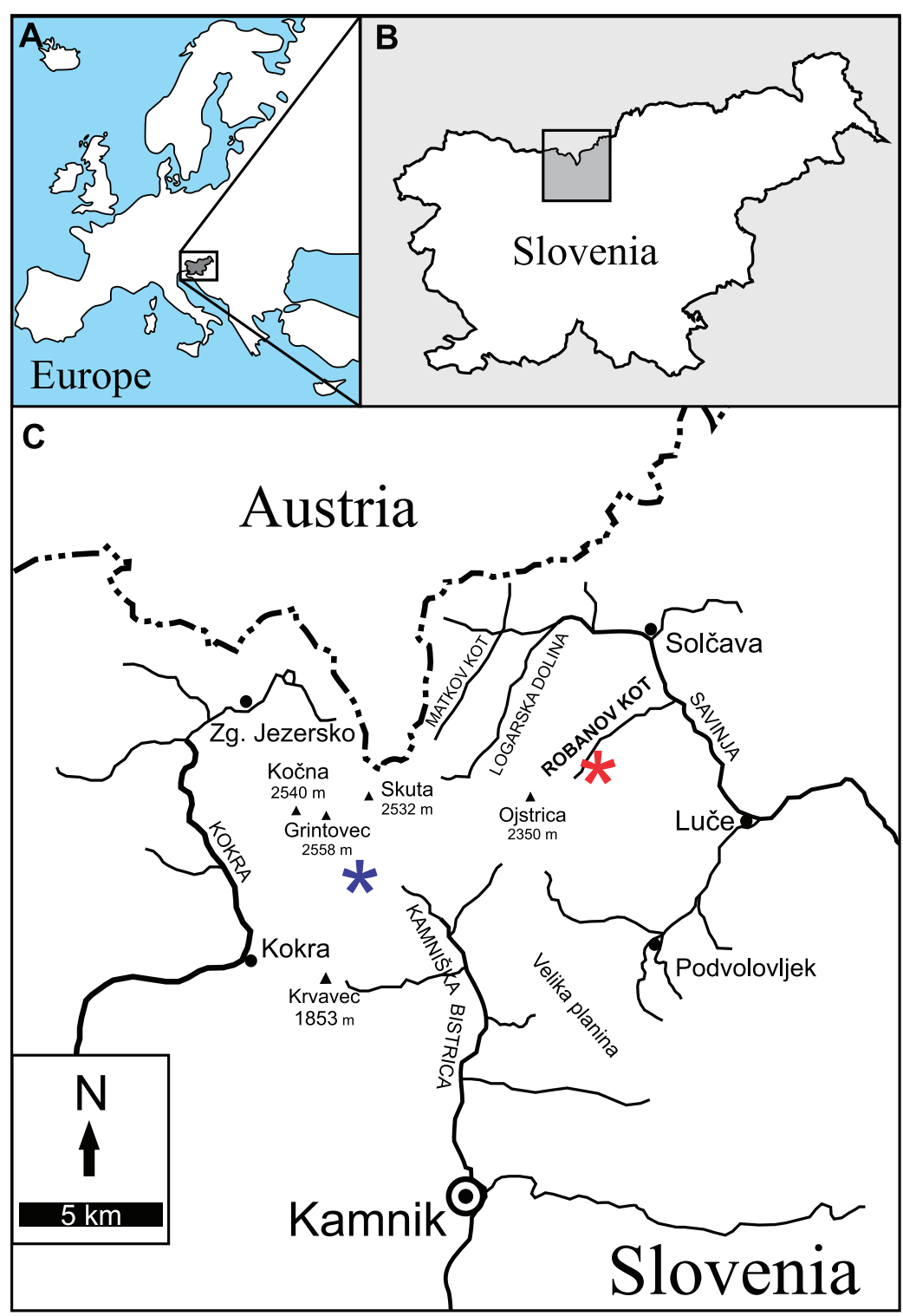

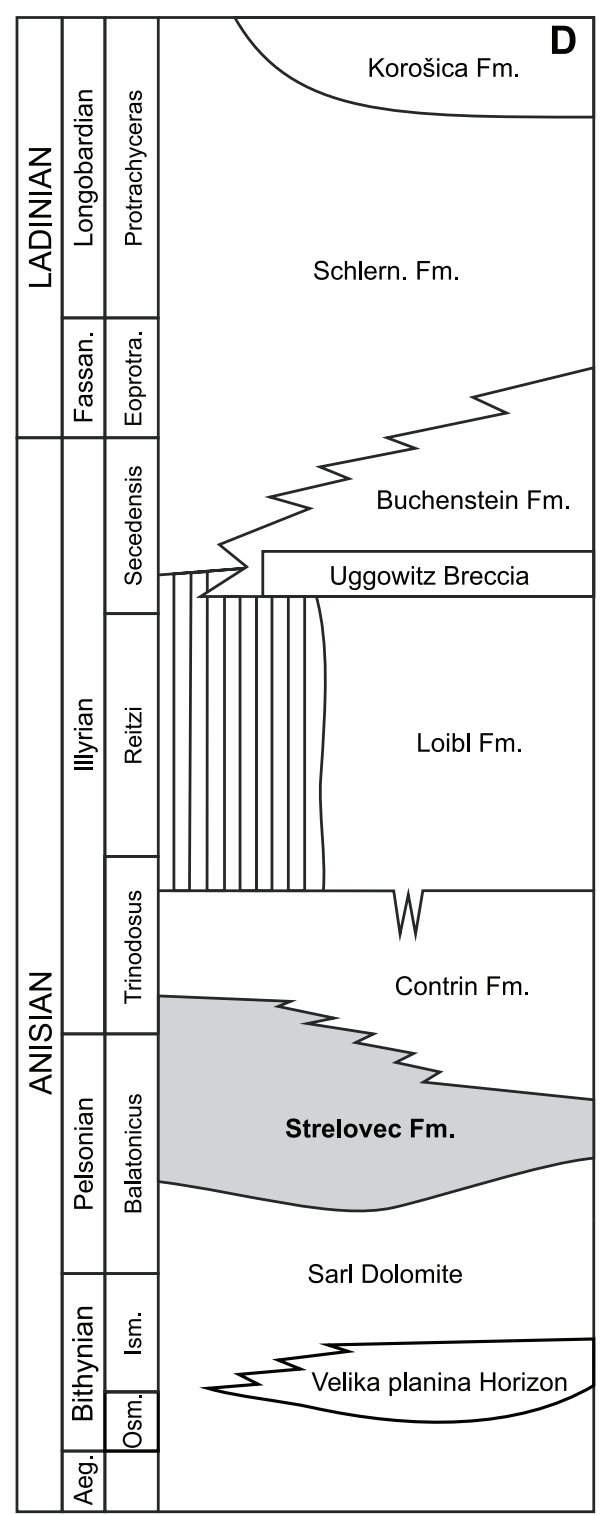

FIGURE 1. Locations of Sloveniolimulus rudkini specimens and the geological context of the Strelovec Formation. A: Map of Europe. Box shows close up in B. B: Map of Slovenia. Box shows close up in C. C: Close up of specimen localities. Red star indicates holotype locality. Blue star indicates location of new material from the Kalška gora Mountain. D: Stratigraphic position of Strelovec Formation. 
We follow the systematic taxonomy of Lamsdell $(2016,2020)$ and Bicknell et al. (2021a) and anatomical terms of Bicknell et al. $(2018,2020)$. Photographs of other xiphosurids were made by the authors or requested from collection managers for comparison.

\section{INSTITUTIONAL ACRONYMS}

MMF: Geological Survey of New South Wales, Londonderry, New South Wales, Australia. PMSL: Slovenian Museum of Natural History, Ljubljana, Slovenia. SSN: Paläontologisches Museum Nierstein, Nierstein, Germany. USNM: United States National Museum, Washington, DC, USA. UTGD: Geology Department, University of Tasmania, Tasmania, Australia.

\section{SYSTEMATIC PALAEONTOLOGY}

Suborder LIMULINA Richter and Richter, 1929

Genus Sloveniolimulus Bicknell et al., 2019b

Sloveniolimulus rudkini Bicknell et al., 2019b

Figures 2, 3

?Limulitella or ?Psammolimulus Križnar and Hitij, p. 96

2019b Sloveniolimulus rudkini Bicknell et al., figs. 5,6

2019a Sloveniolimulus rudkini Bicknell et al., Bicknell, p. 6

2020 Sloveniolimulus rudkini Bicknell et al., Bicknell and Pates, fig. 32C

2020 Sloveniolimulus rudkini Bicknell et al., Lamsdell, possible nomen dubium, p. 28.

2021a Sloveniolimulus rudkini Bicknell et al., Bicknell et al., fig. 7.
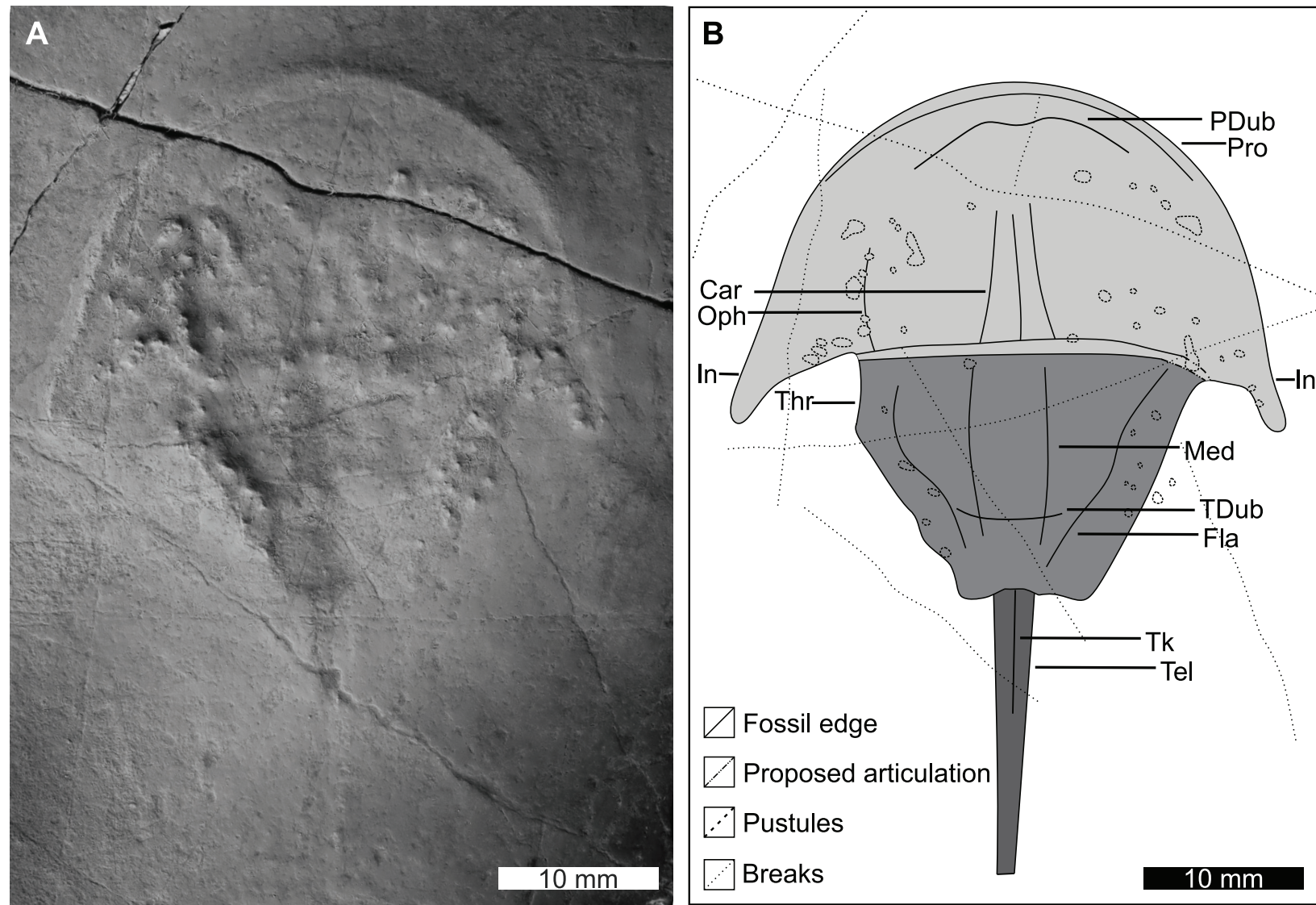

FIGURE 2. Holotype of Sloveniolimulus rudkini. A: PMSL T-993. B: Interpretative drawing of PMSL T-993, colour coded for main body sections. Specimen from the Section S1 of the Slatinski Plaz, Robanov Kot Valley. A coated in ammonium chloride sublimate and images converted to greyscale. Abbreviations: Car: cardiac lobe; Fla: thoracetronic flange; In: genal spine indentation; Med: medial thoracetronic lobe; Oph: ophthalmic ridge; PDub: prosomal doublure; Pro: prosoma; TDub: thoracetronic doublure; Thr: thoracetron; Tel: telson; Tk: telson keel. Image credit: Russell Bicknell. 

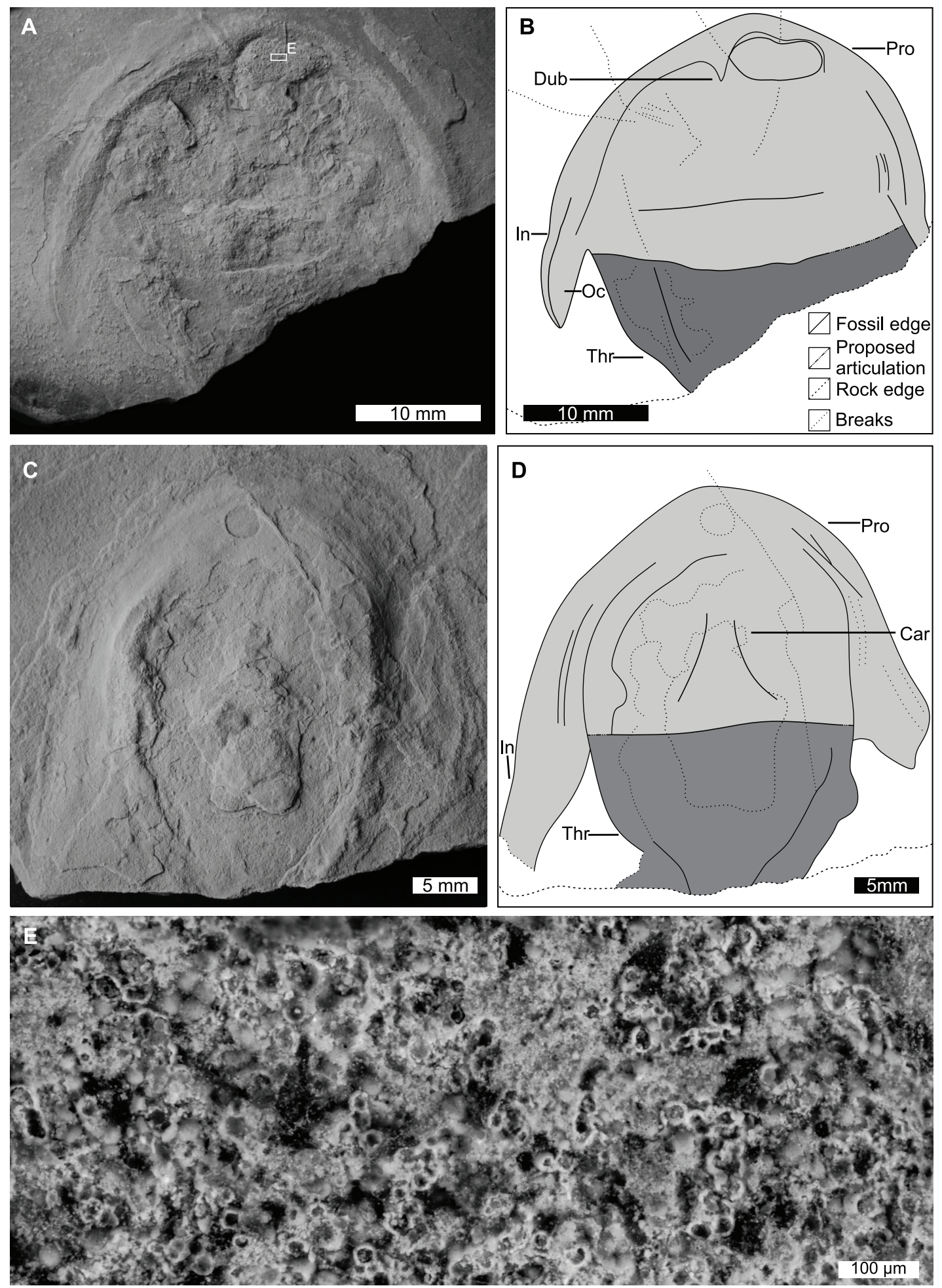

FIGURE 3. New material referred to Sloveniolimulus rudkini. A, B, E: PMSL T-2071. A: Specimen showing prosomal doublure and possible occipital lobe on left genal spine. B: Interpretative drawing of PMSL T-2071. E: Close up of phosphatized spheres in A. C, D: PMSL T-2072. C: Specimen showing injured right genal spine and hypertrophied left genal spine. D: Interpretative drawing of PMSL T-2072. Specimens from the Western slopes of the Kalška gora Mountain, within the Kamniška Bistrica Valley. $\mathbf{B}$ and $\mathbf{D}$ colour coded for main body sections. A and $\mathbf{C}$ coated in ammonium chloride sublimate. All images converted to greyscale. Abbreviations: Car: cardiac lobe; In: genal spine indentation; Oc: possible occipital lobe; Pro: prosoma; Thr: thoracetron. Image credit: A, C: Russell Bicknell; E: Tomaž Hitij. 
2021b Sloveniolimulus rudkini Bicknell et al., Bicknell et al., p. 1468

Holotype. PMSL T-993.

Referred material. PMSL T-2071; PMSL T-2072.

Distribution. Strelovec Formation, Kamnik-Savinja Alps, Slovenia; Middle Triassic (Anisian).

Type locality and horizon. Unit 2 of the Strelovec Formation in Section S1 of the Slatinski Plaz, Robanov Kot Valley, Kamnik-Savinja Alps, Slovenia.

Referred material locality. Western slopes of the Kalška gora Mountain, within the Kamniška Bistrica Valley. Above Unit 2 of the Strelovec Formation, no exact stratigraphic data.

Amended diagnosis. Limuloid with genal spine splay and indentations along spines. Genal spine indentations occur within last quarter of spine length.

Preservation. PMSL T-993 is preserved as a flattened, external mould in black, thin-bedded limestone. Pustule structures within and around the specimen are present, asymmetric and random. These structures reflect either the precipitation of a mineral phase in bacterial mats, or diagenetic mineral precipitation within the exoskeleton during fossilisation (Briggs and Wilby, 1996; Tetlie and Van Roy, 2006; Iniesto et al., 2016). PMSL T-2071 and PMSL T-2072 are preserved as domed internal moulds on brown-yellow, thin bedded limestones without the pustulose structures observed in PMSL T-993. The preservational mode of all specimens limits the record of delicate features, such as lateral compound eyes, ocelli, and appendages.

Description. The holotype, PMSL T-993, is an articulated prosoma, thoracetron, and partial telson (Figure 2). Specimen $57.8 \mathrm{~mm}$ long. Prosoma parabolic in shape, $16.1 \mathrm{~mm}$ long at midline and 39.5 $\mathrm{mm}$ wide between distal genal spine points. Prosomal rim $\sim 1.0 \mathrm{~mm}$ wide. Left ophthalmic ridge present, albeit surrounded by pustules, has slight concavity, $7.7 \mathrm{~mm}$ long. Section of prosomal doublure noted. Cone shaped cardiac lobe observed under low angle light, $6.5 \mathrm{~mm}$ wide posteriorly, tapering to $3.4 \mathrm{~mm}$. Cardiac lobe medial ridge 6 $\mathrm{mm}$ long. Genal spines splay slightly, extend posterolaterally, and terminate within first third of thoracetron length. Both spines have an indentation 4 $\mathrm{mm}$ from spine termini. Left genal spine terminus $20.2 \mathrm{~mm}$ from midline. Angle between left genal spine and left side of thoracetron $62^{\circ}$. Right genal spine $19.5 \mathrm{~mm}$ from midline. Angle between right genal spine and right side of thoracetron $64^{\circ}$. Prosomal-thoracetron hinge pronounced, $20.8 \mathrm{~mm}$ wide, $1.5 \mathrm{~mm}$ long. Thoracetron trapezoidal, 15.8 $\mathrm{mm}$ long, $20 \mathrm{~mm}$ wide anteriorly, tapering to $2 \mathrm{~mm}$ posteriorly. Thoracetronic flange defined mostly by pustules. Thoracetronic doublure evident along margins and thoracetronic rim $\sim 1.5 \mathrm{~mm}$ wide. Medial thoracetronic lobe rectangular, $17.1 \mathrm{~mm}$ long, $4.5 \mathrm{~mm}$ wide, lacks ridge. Posterior margin of thoracetronic doublure imprinted over medial thoracetronic lobe. Pleural lobes lack relief and segmentation. Left pleural lobe $5.7 \mathrm{~mm}$ wide anteriorly, tapering to $2.3 \mathrm{~mm}$. Right pleural lobe $7.6 \mathrm{~mm}$ wide anteriorly, tapering to $2.2 \mathrm{~mm}$. Moveable spine notches on right side. Thoracetron-telson embayment weakly concave. Telson $23.2 \mathrm{~mm}$ long, anterior section of telson keel present.

PMSL T-2071 is an articulated prosoma and partial thoracetron (Figure 3A-B, E). Specimen $23.6 \mathrm{~mm}$ long. Prosoma parabolic in shape, 16.1 $\mathrm{mm}$ long at midline, $35.0 \mathrm{~mm}$ wide between left genal spine point and rock edge on right side. Prosomal doublure prominent, a possible ventral perspective. Prosomal rim $\sim 1.0 \mathrm{~mm}$ wide. Left genal spine extends posterolaterally, terminates within first third of thoracetron length. Right genal spine absent. Left spine has an indentation $6 \mathrm{~mm}$ from spine terminus. Left genal spine terminus $18.8 \mathrm{~mm}$ from midline. Possible occipital lobe section extends along spine. Angle between left genal spine and left side of thoracetron $44.7^{\circ}$. A white to light brown section on right side of prosoma noted (Figure 3E). Within this region, minute, $\sim 30 \mu \mathrm{m}$ wide spheres observed. Thoracetron broken at rock edge, measurements are therefore not indicative of true size. Thoracetron trapezoidal, $7.5 \mathrm{~mm}$ long, $24.7 \mathrm{~mm}$ wide anteriorly. Thoracetronic rim $0.8 \mathrm{~mm}$ wide.

PMSL T-2072 is an articulated prosoma and partial thoracetron (Figure 3C-D). Specimen 32.5 $\mathrm{mm}$ long. Prosoma parabolic in shape, $19.2 \mathrm{~mm}$ long at midline, and $33.9 \mathrm{~mm}$ wide between genal spine points. Prosomal rim $0.9 \mathrm{~mm}$ wide. Coneshaped cardiac lobe observed under low angle light, $6.3 \mathrm{~mm}$ wide posteriorly, tapering to $2.8 \mathrm{~mm}$. Genal spines extend posterolaterally and terminate at halfway along thoracetron. Left spine has indentation $7.4 \mathrm{~mm}$ from spine terminus. Spine terminus $20.2 \mathrm{~mm}$ from midline. Angle between left genal spine and left side of thoracetron $54.2^{\circ}$. Right genal spine stunted; likely damaged during life and a possible record of predation. Posteriormost section of right genal spine $16.7 \mathrm{~mm}$ from midline. Angle between right genal spine and right side of thoracetron $56.1^{\circ}$. Thoracetron trapezoidal, $13.3 \mathrm{~mm}$ long, $20.8 \mathrm{~mm}$ wide anteriorly, terminating at rock edge. Thoracetron flange evident along right margin. 

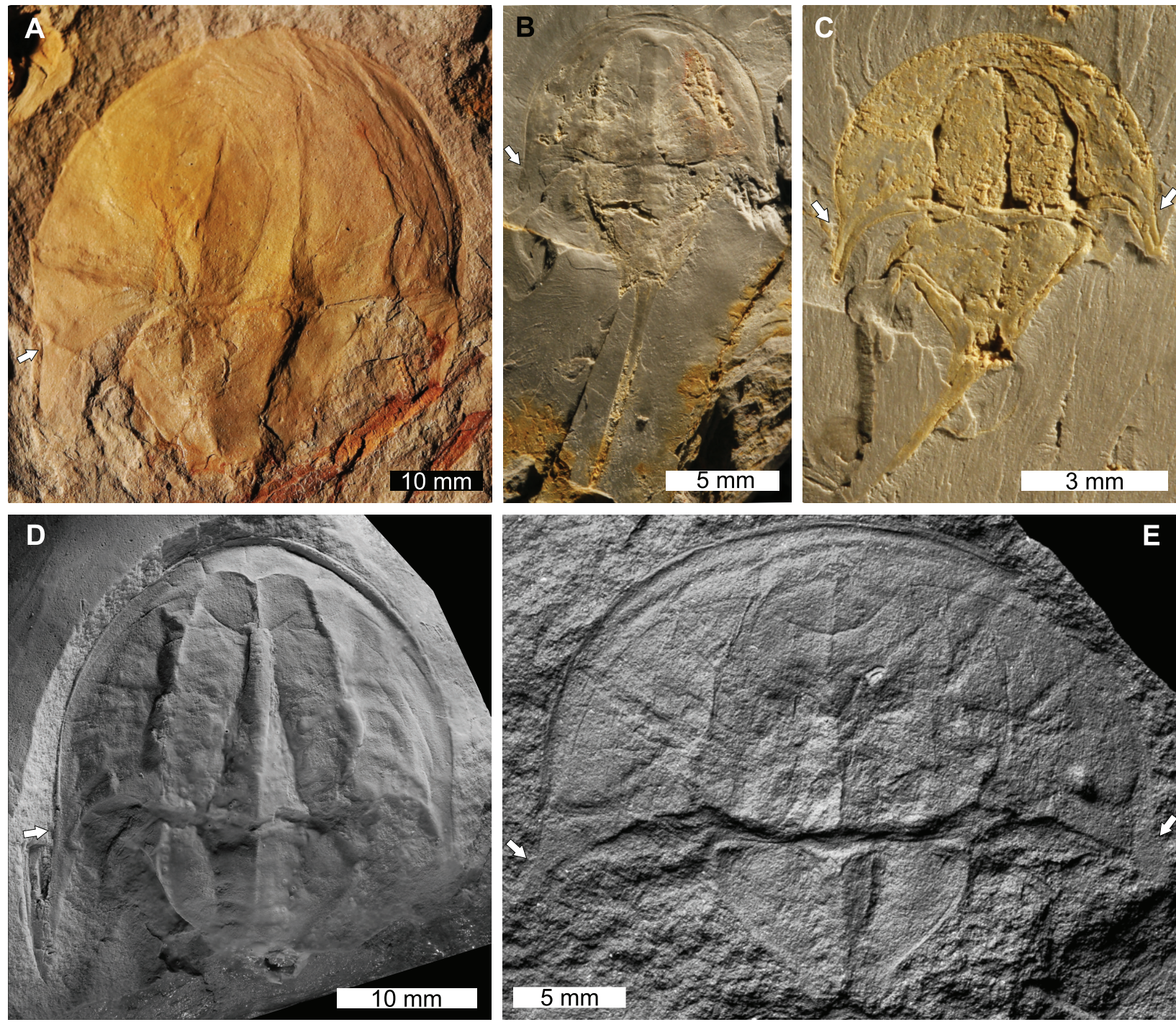

FIGURE 4. Additional xiphosurids with genal spine indentations. Arrows indicate the structure on all taxa. A: Franconiolimulus pochankei from the Bayreuth Formation, (Early Jurassic, Hettangian) Pechgraben, Germany. SSN 8PG35, holotype. B, C: Panduralimulus babcocki from the Maybelle Limestone, Lueders Formation (Permian, Cisuralian, Kungurian), Texas, USA. B: USNM 520723, holotype. C: USNM 520724, paratype. D: Tasmaniolimulus patersoni from the Jackey Shale (Permian, Lopingian), Tasmania, Australia. UTGD 123979, holotype. E: Dubbolimulus peetae from the Ballimore Formation (Middle Triassic, Ladinian), New South Wales, Australia. MMF 27693, holotype. D coated in ammonium chloride sublimate. D and E converted to greyscale. Image credit: A: Andreas Hecker; B-D: Russell Bicknell; E: David Barnes.

Remarks. Re-examining Sloveniolimulus rudkini, we agree with Lamsdell's observation that there are few diagnostic features present on these fossils. However, indentations along S. rudkini genal spines are a cardinal morphological feature that differentiates this material from other Triassic xiphosurid taxa. Such genal spine indentations (or kinks) are known from other taxa (e.g., Dubbolimulus peetae Pickett, 1984, Franconiolimulus pochankei Bicknell, et al. 2021b, Panduralimulus babcocki Allen and Feldmann, 2005, Tasmaniolim- ulus patersoni Bicknell, 2019; Figure 4). The presence of this feature in all specimens considered here, as well as multiple other taxa, illustrates that it is not a taphonomic artefact (sensu Lamsdell, 2020). Furthermore, genal spine morphologies are a useful feature for determining genera (see Bicknell, 2019; Bicknell et al., 2021b; Figure 4). The presence of this morphology, coupled with the genal spine splay and position of the ophthalmic ridge (when compared to $T$. patersoni and $F$. 
pochankei, the most morphologically similar taxa) are sufficient evidence for maintaining $S$. rudkini.

The new material presents an interesting taxonomic puzzle: PMSL T-2072 has genal spines terminating circa halfway along the thoracetron. This hypertrophy of genal aligns the Strelovec Formation material with Austrolimulidae, rather than Limulidae (contra Bicknell et al., 2019b, 2021a). Indeed, many Permo-Triassic austrolimulids have overdeveloped genal spines (Riek, 1955; Meischner, 1962; Allen and Feldmann, 2005; Lerner et al., 2017; Bicknell, 2019). However, austrolimulids are typically considered marginal- to non-marine organisms (Lamsdell, 2016; Bicknell and Pates, 2020) and, despite limited plant remains, the Strelovec Formation represents a marine palaeoenvironment (Miklavc et al., 2016); an observation that contradicting an austrolimulid assignment. Nonetheless, given this uncertainty, we currently place Sloveniolimulus rudkini within the Superfamily Limuloidea, but not within a family.

Two other possible explanations for the morphological variants should be discussed. The first is that there are two horseshoe crab groups preserved within the Strelovec Formation, and the second is that the hypertrophied genal spines reflect sexual dimorphism. The first alternative is plausible, especially as multiple taxa from different families have been documented in the same deposit (see Raymond, 1944; Bicknell et al., in press). However, to avoid the potential over-splitting of limited material, we presently do not support this thesis. The concept of sexual dimorphism is intriguing, especially as reduced moveable spines in females of extant taxa are known-consider female Tachypleus tridentatus (Leach, 1819) (Shuster Jr., 1982; Botton et al., 1996). However, hypertrophied genal spines have not previously been considered sexually selected characteristics. Furthermore, suggesting genal spine hypotrophy reflected such selection would require many assumptions regarding structures that can be sexually selected and is not an overly parsimonious explanation. As such, at this point, we do not support this second idea. In sum, the Strelovec Formation xiphosurids presented here likely represent the morphological extremes of the same taxon.

In re-examining the material, we identified three points that differ from the original Bicknell et al. (2019b) description. We illustrate that (1) Sloveniolimulus rudkini ophthalmic ridges are concave, not straight, (2) the supposed operculum observed by Bicknell et al. (2019b) likely reflects a thorace- tronic doublure, and (3) the telson of PMSL T-993 is slightly longer than previously documented.

The spheres in PMSL T-2071 (Figure 3E) resemble phosphatised coccoid microbes observed on the Late Jurassic-aged Nusplingen Mesolimulus walchi (Briggs et al., 2005). However, the spheres in PMSL T-2071 are approximately three times larger than those documented by Briggs et al. (2005). Despite this size, they fall well within the size limits of microbes (sensu Levin and Angert, 2015), indicating that the spheres are indeed evidence of microbial activity.

\section{DISCUSSION}

The mode of xiphosurid preservation within the Strelovec Formation is similar to other Mesozoic Konservat-Lagerstätten. It is most comparable to the Middle Triassic (Anisian)-aged Guanling Formation, China (Hu et al., 2011, 2017), the Middle Triassic (Ladinian)-aged Montral-Alcover Konservat-Lagerstätte, Spain (Vía and De Villalta, 1966; Vía et al., 1977; Vía Boada, 1987), and the Late Jurassic (Kimmeridgian-early Tithonian)-aged Solnhofen and Nusplingen limestones, Germany (Briggs et al., 2005). Horseshoe crab specimens from these limestones are preserved as flattened or slightly domed impressions, showing dorsal and ventral anatomy, and occasionally showing appendages (Bicknell et al., 2019a) and other softpart anatomy (Briggs et al., 2005). Horseshoe crab preservation within such limestones likely occurred through a three-step process: (1) organic remains were embedded in microbial mats, (2) detailed impressions were produced within the mat, (3) a mineral phase precipitated and stabilised the impression for burial and lithification (Iniesto et al., 2016). Such mineralised microbes are observed in horseshoe crab fossils from the Nusplingen Limestone (Briggs et al., 2005) and similar structures were also found in PMSL T-2071.

The cuticular exoskeleton of horseshoe crabs is much weaker than the biomineralised dorsum of trilobites (Babcock, 2003; Pérez-Huerta et al., 2018) and the mineralised chitin of some crustaceans (Bentov et al., 2016). As such, xiphosurids have a limited preservation potential. Given the presence of the forms in the Strelovec Formation, it is striking that the fauna preserved within the predominantly hypoxic and/or anoxic conditions have been so minimally documented (although see Križnar and Hitij, 2010; Žalohar and Hitij, 2010; Celarc et al., 2013; Tintori et al., 2014). Indeed, there is a diverse array of metazoan remains docu- 

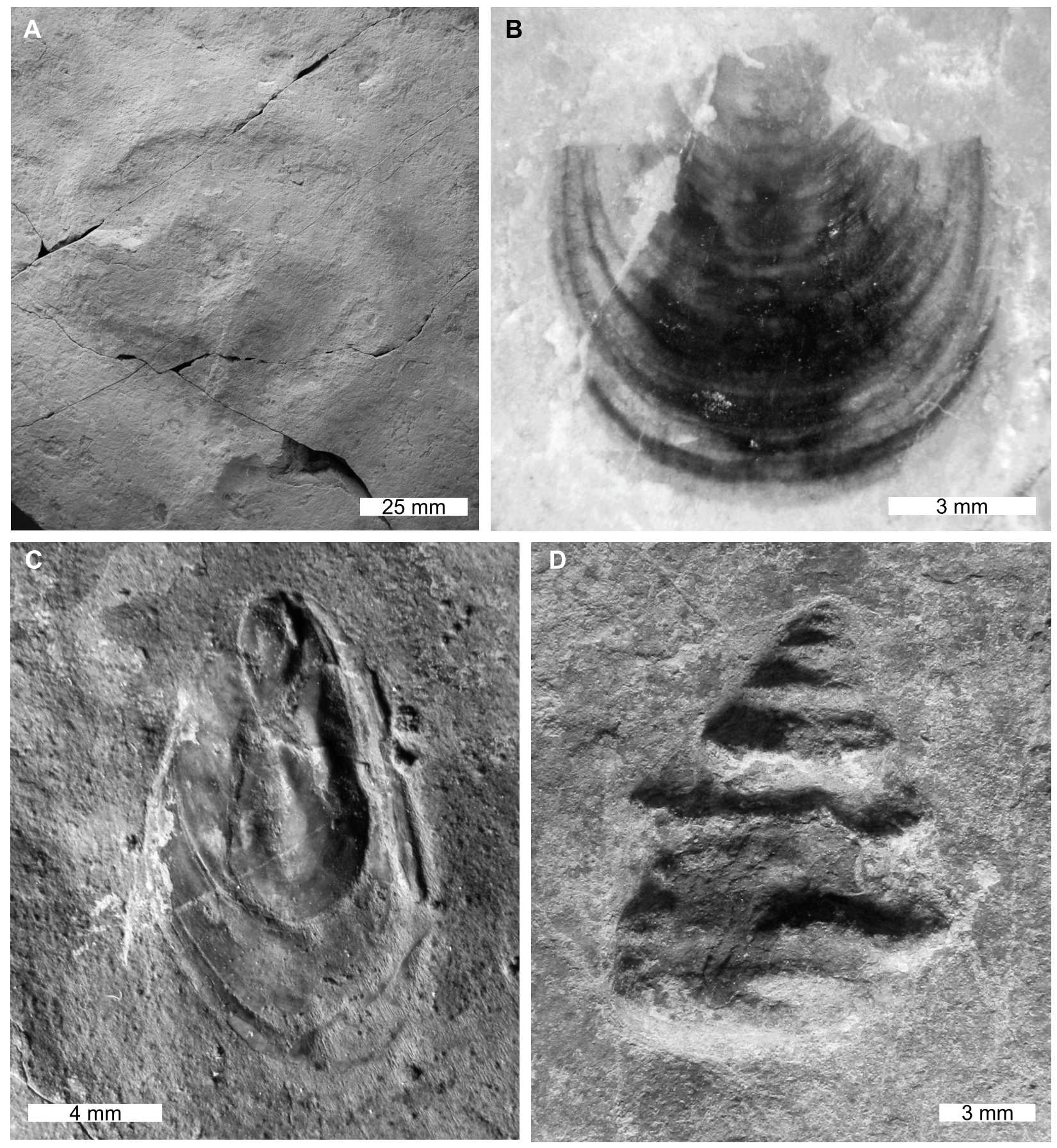

FIGURE 5. Molluscs and brachiopods from the Strelovec Formation. A: An ammonoid. PMSL T-1805. B: Lingulid brachiopod. PMSL T-865. C: Modiolus sp. PMSL T-836. D: Worthenia sp. PMSL T-1772. A coated in ammonium chloride sublimate. All converted to greyscale. Image credit: A: Tomaž Hitij; B, C, D: Jure Žalohar.

mented from the formation that preserve informative taxonomic and taphonomic information.

A variety of invertebrate groups are known from the Strelovec Formation (Figure 5A, C-D). Among these, ammonoid specimens are especially rare. This likely reflects preservational bias-identified ammonoids are preserved as one-dimensional imprints with evidence of aragonitic shell corrosion (Buchardt and Weiner, 1981). This indicates the material was deposited proximal to, or below the aragonite compensation depth (Lehmann, 2000; Bernoulli and Jenkyns, 2009). Such corrosion is also observed on the calcite shell of bivalves and gastropods (Figure 5C-D). Conversely, organisms 

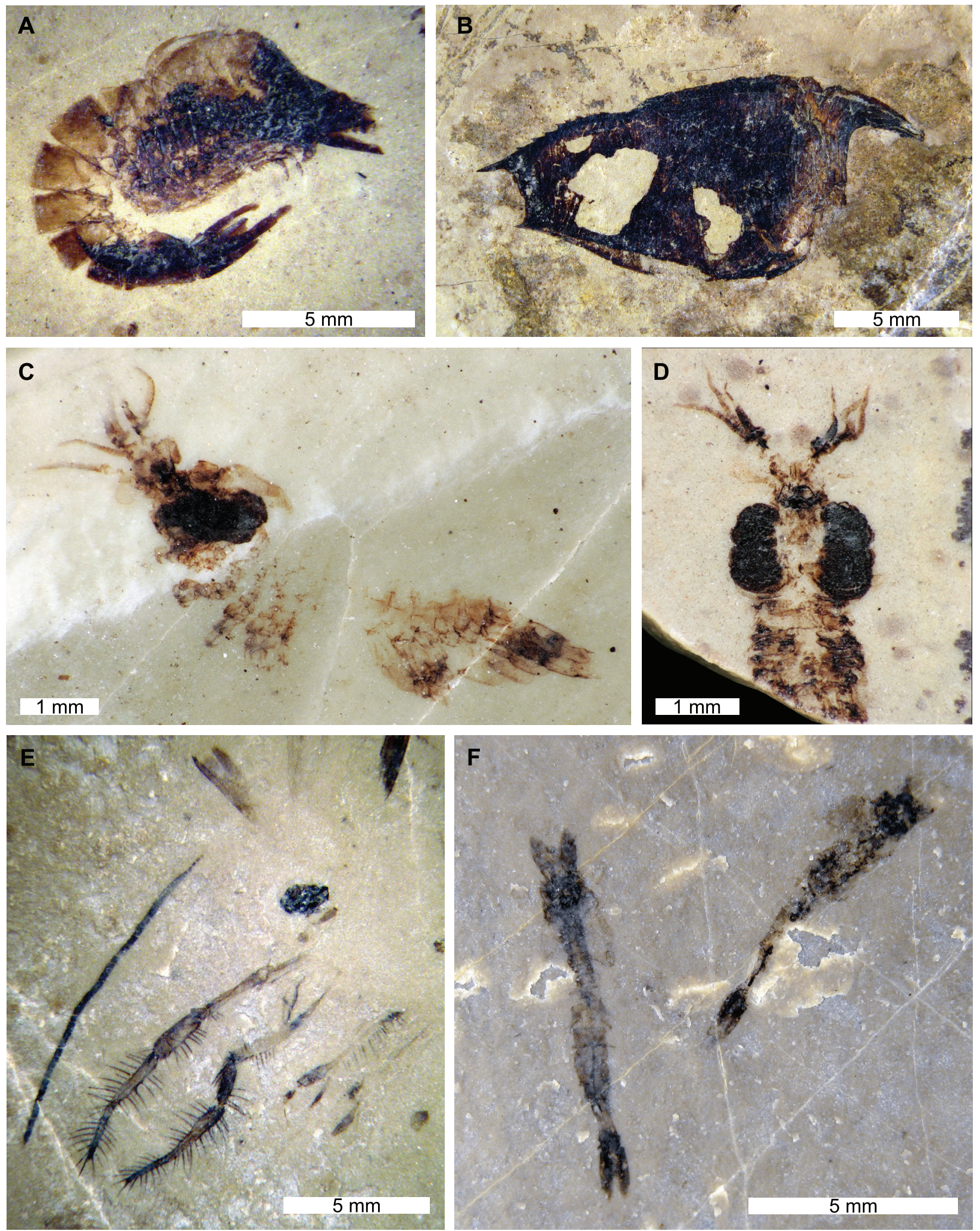

FIGURE 6. Non-xiphosurid euarthropods from the Strelovec Formation. A, E: Aeger sp. A: PMSL T-1270. E: PMSL T1238 showing exceptional appendage detail. B: An as-of-yet undescribed thylacocephalan. PMSL T-1742. C, D: Exceptionally well-preserved indeterminate decapod crustaceans. C: PMSL T-1262 showing appendage segmentation and ocular structures. D: PMSL T-1263. F: Schimperella sp. PMSL T-1236. Image credit: Jure Žalohar. 

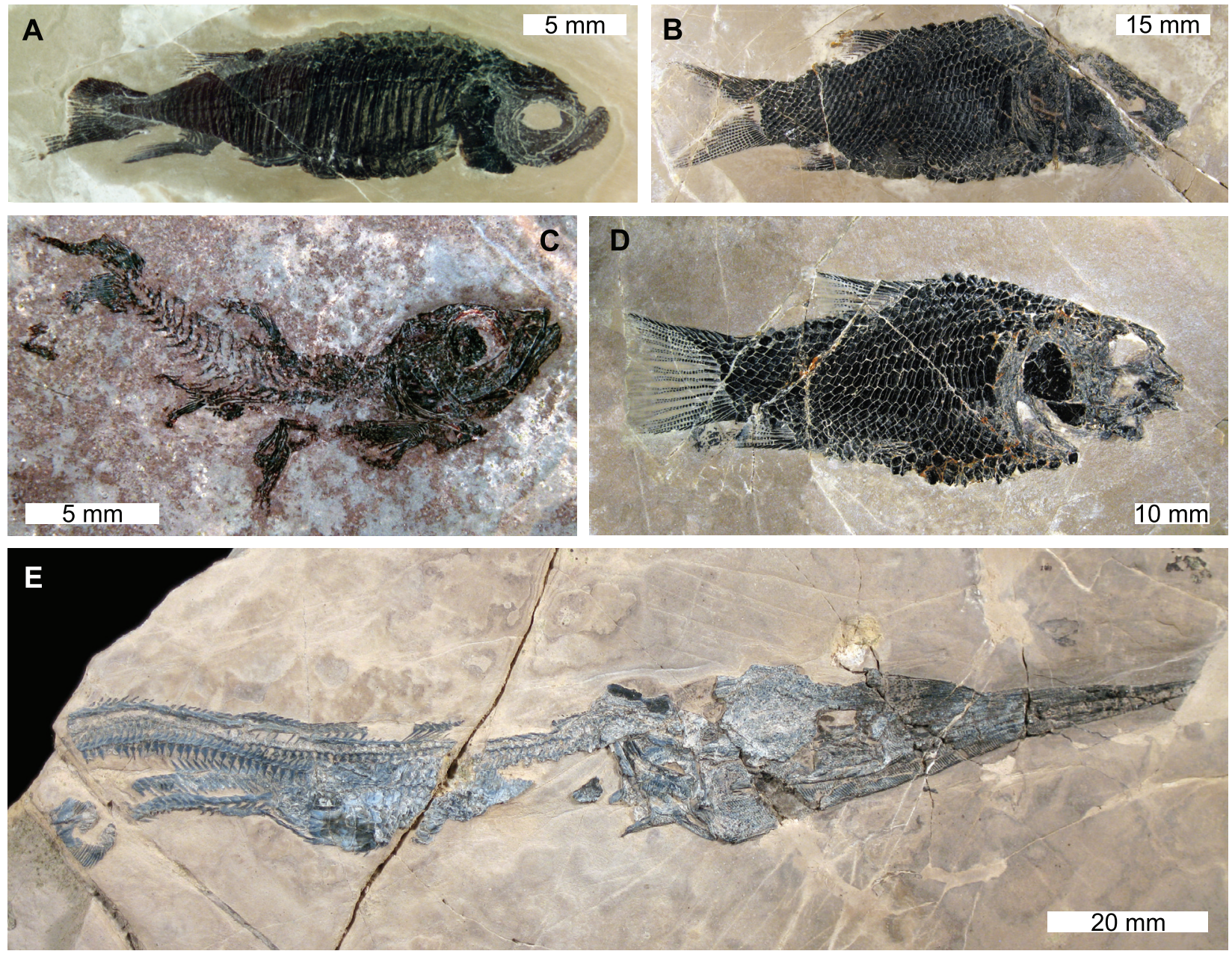

FIGURE 7. Marine vertebrates from the Strelovec Formation. A: Placopleurus sp. PMSL T-899. B: Sangiorgioichthys sp. PMSL T-900. C: Marcopoloichthys sp. preserving ocular structures. PMSL T-1745. D: Eosemionotus sp. PMSL T1262. E Saurichthys sp. with stomach contents containing Eosemionotus sp. A and E reflected to align with other images. Image credit: Jure Žalohar.

with predominantly chitinous exoskeletons or organophosphatic shells are well preserved. As such, inarticulate brachiopods (Figure 5B) and crustaceans are abundant (Figure 6). Crustaceans, in particular, show exceptional detail, with even the smallest specimens preserving extremely fine details like hairs and eyes (Križnar and Hitij, 2010; Feldmann et al., 2017; Figure 6C, E).

Skeletal components of Strelovec Formation vertebrates are also exceptionally well preserved. Fully articulated fish and reptile skeletons are common (Celarc et al., 2013; Tintori et al., 2014; Miklavc et al., 2016; Figure 7). The bones are often surrounded by pyrite, with rarer records of soft tissue imprints. This pyritisation occurs through bacterial sulphate reduction that is typical of anoxic bottom layers (Schiffbauer et al., 2014), further supporting the interpretation of anoxia that permitted the record of such details.

Clearly, there is a wealth of novel material within this exceptional deposit that requires examination. Further taxonomic and population-based studies, comparable to the work on the Luoping biota (Hu et al., 2011, 2017; Benton et al., 2013), will undoubtedly present insight into the recovery of communities from the end-Permian extinction, and the rise of 'modern' marine ecosystems.

\section{ACKNOWLEDGEMENTS}

This research was supported by funding from a Research Training Program Scholarship (to R.D.C.B.), a University of New England Postdoctoral Research Fellowship (to R.D.C.B.), a James R. Welch Scholarship (to R.D.C.B.), and a Betty Mayne Scientific Research Fund (to R.D.C.B.). We 
thank A. Hecker and D. Barnes for specimen images. We thank the editors C. Haug and J. Fan for handling the manuscript. Finally, we thank two anonymous referees for their comments that improved the scope, direction, and use of the text.

\section{IN MEMORY OF BOGOMIR CELARC (1971-2021)}

We dedicate this article Revisiting horseshoe crab fossils from the Middle Triassic (Anisian) Strelovec Formation Konservat Lagerstätte to our friend Bogomir, who unexpectedly passed during the course of writing this publication.

Bogomir's life was, from his youth, tightly connected to the mountains and caves. Bogomir was not just an exceptional regional geologist, but also a climber, a caver, an outstanding mentor, and a family man. He was an active member and then president of the mountaineering association and caving club in Borovnica. He climbed most of the Slovenian classic climbing routes, from the Aschenbrenner route in the Travnik mountain to the Helba-Čop combination in the Triglav mountain wall, as well as other ranges across the globe. He also passed on much mountaineering knowledge to younger. As a caver, he explored and recorded new caves mostly on the Mejniška plateau. In the late 1980s, he scaled a $40 \mathrm{~m}$ high chimney in the Malenska abyss, a unique feat at the time. Few years later in the same abyss, a severe caving accident happened to him, when a fallen rock broke both of his arms. Despite the traumatic experience, Bogomir continued to explore the caves.

With his interest in rocks, it is not surprising that he wanted to peruse geology. His outdoor skills allowed him to collect geological samples in very remote places which greatly contributed to the development of Slovenian geological science. After his diploma Geological structure of the territory around Borovnica he took a position in the Geological Survey of Slovenia working towards his place as head of the Regional Geology Department. As a classical regional geologist, he was distinguished by an exceptional sense of space and structure and a detailed knowledge of stratigraphy, so he was considered an extremely good mapping geologist publishing over 100 works. In his leadership position, he was unable to so easily conduct the field work that he loved. Despite these limitations, by 2021 he had still produced 22 original scientific articles detailing Triassic stratigraphy, structural geology, and tectonics.

Bogomir's interest in the Sloveinan Alps arose during his doctorate. He opted to explore remote mountain valleys of the northeastern Kamnik-Savinja Alps in the hard-to-reach walls of Robanov kot Valley, Logarska dolina Valley and Matkov kot Valley. In doing so, he realized that his observations contradicted his mentor and turned to Dr Piero Gianollo from Italy-currently the greatest stratigrapher of the Italian Dolomites and the Julian Alps. With his help, Bogomir overturned the views on Slovenian Triassic stratigraphy and laid the foundations of all the later research. Following Bogomir's doctoral thesis, numerous exceptional Triassic vertebrate deposits in the Kamnik-Savinja Alps have been discovered. These included the Slatinski plaz fossil site containing the Sloveniolimulus holotype. Unfortunately, he will never see the publications on the sedimentary development of the Velika planina Member and on the filling of the Middle Triassic half-graben below the Vernar Mountain.

Before his premature passing, Bogomir had big plans for his future work. He will be impossible to replace, but we will try our best to continue his work. We will always remember him as a little reserved, always realistic, and insightful in his words. We will remember his kind and unobtrusive character, his simplicity and modesty. When Bogo spoke, we all listened, as he had an extremely good spatial representation, an understanding of structural geology, and an extraordinary amount of field experience. He always tried to be open, honest and constructive, so it was easy and pleasant to work with him. Bogomir will always stay in our minds and we will miss him as a man, a co-worker, and above all a friend.

Bogo, we will be forever grateful for the time we spent together. Rest in peace!

\section{REFERENCES}

Allen, J.G. and Feldmann, R.M. 2005. Panduralimulus babcocki n. gen. and sp., a new Limulacean horseshoe crab from the Permian of Texas. Journal of Paleontology, 79:594-600. https://doi.org/10.1666/0022-3360(2005)079<0594:pbngas>2.0.co;2 
Babcock, L.E. 2003. Trilobites in Paleozoic predator-prey systems, and their role in reorganization of early Paleozoic ecosystems, p. 55-92. In Kelley, P., Kowalewski, M., and Hansen, T.A. (eds.), Predator-Prey interactions in the Fossil Record. Springer, New York.

Benton, M.J., Zhang, Q., Hu, S., Chen, Z.-Q., Wen, W., Liu, J., Huang, J., Zhou, C., Xie, T., and Tong, J. 2013. Exceptional vertebrate biotas from the Triassic of China, and the expansion of marine ecosystems after the Permo-Triassic mass extinction. Earth-Science Reviews, 125:199-243. https://doi.org/10.1016/j.earscirev.2013.05.014

Bentov, S., Abehsera, S., and Sagi, A. 2016. The mineralized exoskeletons of crustaceans, p. 137-163. In Cohen, E. and Moussian, B. (eds.), Extracellular Composite Matrices in Arthropods. Springer International Publishing, Cham. https://doi.org/10.1007/978-3-319-40740-1_5

Bernoulli, D. and Jenkyns, H.C. 2009. Ancient oceans and continental margins of the AlpineMediterranean Tethys: Deciphering clues from Mesozoic pelagic sediments and ophiolites. Sedimentology, 56:149-190. https://doi.org/10.1111/j.1365-3091.2008.01017.x

Bicknell, R.D.C. 2019. Xiphosurid from the Upper Permian of Tasmania confirms Palaeozoic origin of Austrolimulidae. Palaeontologia Electronica, 22.3.62A:1-13. https://doi.org/10.26879/1005

Bicknell, R.D.C. and Pates, S. 2020. Pictorial atlas of fossil and extant horseshoe crabs, with focus on Xiphosurida. Frontiers in Earth Science, 8:60. https://doi.org/10.3389/feart.2020.00098

Bicknell, R.D.C., Klinkhamer, A.J., Flavel, R.J., Wroe, S., and Paterson, J.R. 2018. A 3D anatomical atlas of appendage musculature in the chelicerate arthropod Limulus polyphemus. PLoS ONE, 13:e0191400. https://doi.org/10.1371/journal.pone.0191400

Bicknell, R.D.C., Brougham, T., Charbonnier, S., Sautereau, F., Hitij, T., and Campione, N.E. 2019a. On the appendicular anatomy of the xiphosurid Tachypleus syriacus and the evolution of fossil horseshoe crab appendages. The Science of Nature, 106:38. https://doi.org/10.1007/s00114-019-1629-6

Bicknell, R.D.C., Žalohar, J., Miklavc, P., Celarc, B., Križnar, M., and Hitij, T. 2019b. A new limulid genus from the Strelovec Formation (Middle Triassic, Anisian) of northern Slovenia. Geological Magazine, 156:2017-2030. https://doi.org/10.1017/S0016756819000323

Bicknell, R.D.C., Naugolnykh, S.V., and Brougham, T. 2020. A reappraisal of Paleozoic horseshoe crabs from Russia and Ukraine. The Science of Nature, 107:46. https://doi.org/10.1007/s00114-020-01701-1

Bicknell, R.D.C., Błażejowski, B., Wings, O., Hitij, T., and Botton, M.L. 2021a. Critical reevaluation of Limulidae reveals limited Limulus diversity. Papers in Palaeontology, 7:15251556. https://doi.org/10.1002/spp2.1352

Bicknell, R.D.C., Hecker, A., and Heyng, A.M. 2021b. New horseshoe crab fossil from Germany demonstrates post-Triassic extinction of Austrolimulidae. Geological Magazine, 158:14611471. https://doi.org/10.1017/S0016756820001478

Bicknell, R.D.C., Naugolnykh, S.V., and McKenzie, S.C. in press. On Paleolimulus from the Mazon Creek Konservat-Lagerstätte. Comptes Rendus Palevol.

Botton, M.L., Shuster, C.N., Sekiguchi, K., and Sugita, H. 1996. Amplexus and mating behavior in the Japanese horseshoe crab, Tachypleus tridentatus. Zoological Science, 13:151-159. https://doi.org/10.2108/zsj.13.151

Briggs, D.E.G. and Wilby, P.R. 1996. The role of the calcium carbonate-calcium phosphate switch in the mineralization of soft-bodied fossils. Journal of the Geological Society, 153:665668. https://doi.org/10.1144/gsjgs.153.5.0665

Briggs, D.E.G., Moore, R.A., Shultz, J.W., and Schweigert, G. 2005. Mineralization of soft-part anatomy and invading microbes in the horseshoe crab Mesolimulus from the Upper Jurassic Lagerstätte of Nusplingen, Germany. Proceedings of the Royal Society of London B: Biological Sciences, 272:627-632. https://doi.org/10.1098/rspb.2004.3006

Buchardt, B. and Weiner, S. 1981. Diagenesis of aragonite from Upper Cretaceous ammonites: a geochemical case-study. Sedimentology, 28:423-438. https://doi.org/10.1111/j.1365-3091.1981.tb01691.x

Celarc, B. 2004. Geological structure of the northwestern part of the Kamnik Savinja Alps, Ph.D. Thesis, University of Ljubljana: $137 \mathrm{p}$.

Celarc, B., Goričan, Š., and Kolar-Jurkovšek, T. 2013. Middle Triassic carbonate-platform breakup and formation of small-scale half-grabens (Julian and Kamnik-Savinja Alps, Slovenia). Facies, 59:583-610. https://doi.org/10.1007/s10347-012-0326-0 
Feldmann, R.M., Schweitzer, C.E., Hu, S., Huang, J., Zhou, C., Zhang, Q., Wen, W., Xie, T., Schram, F.R., and Jones, W.T. 2017. Earliest occurrence of lophogastrid mysidacean arthropods (Crustacea, Eucopiidae) from the Anisian Luoping Biota, Yunnan Province, China. Journal of Paleontology, 91:100-115. https://doi.org/10.1017/jpa.2016.121

Haas, J., Kovács, S., Krystyn, L., and Lein, R. 1995. Significance of Late Permian-Triassic facies zones in terrane reconstructions in the Alpine-North Pannonian domain. Tectonophysics, 242:19-40. https://doi.org/10.1016/0040-1951(94)00157-5

Hitij, T., Žalohar, J., Celarc, B., Križnar, M., Renesto, S., and Tintori, A. 2010. The kingdom of the Tethys: the fossilized world of Triassic vertebrates from the Kamniško-Savinjske Alps. Scopolia, 5:1-197.

Hu, S.X., Zhang, Q.Y., Chen, Z.Q., Zhou, C.Y., Lü, T., Xie, T., Wen, W., Huang, J.Y., and Benton, M.J. 2011. The Luoping biota: exceptional preservation, and new evidence on the Triassic recovery from end-Permian mass extinction. Proceedings of the Royal Society B: Biological Sciences, 278:2274-2282. https://doi.org/10.1098/rspb.2010.2235

Hu, S.X., Zhang, Q.Y., Feldmann, R.M., Benton, M.J., Schweitzer, C.E., Huang, J.Y., Wen, W., Zhou, C.Y., Xie, T., Lü, T., and Hong, S.G. 2017. Exceptional appendage and soft-tissue preservation in a Middle Triassic horseshoe crab from SW China. Scientific Reports, 7:14112. https://doi.org/10.1038/s41598-017-13319-x

Iniesto, M., Buscalioni, Á.D., Guerrero, M.C., Benzerara, K., Moreira, D., and López-Archilla, A.I. 2016. Involvement of microbial mats in early fossilization by decay delay and formation of impressions and replicas of vertebrates and invertebrates. Scientific Reports, 6:25716. https://doi.org/10.1038/srep25716

Kadivec, K. 2020. Sedimentološka analiza srednjetriasnih breč izpod Vernarja v Julijskih Alpah, Master's thesis, Univerza v Ljubljani.

Križnar, M. and Hitij, T. 2010. Invertebrates of the Strelovec Formation. Scopolia Supplement, 5:91-107.

Lamsdell, J.C. 2016. Horseshoe crab phylogeny and independent colonizations of fresh water: ecological invasion as a driver for morphological innovation. Palaeontology, 59:181-194. https://doi.org/10.1111/pala.12220

Lamsdell, J.C. 2020. The phylogeny and systematics of Xiphosura. PeerJ, 8:e10431. https://doi.org/10.7934/p3497

Leach, W.E. 1819. Entomostraca, p. 524-543. In Levrault, F. (ed.), Dictionaire des Science Naturelles. Levrault and Schoell, Paris.

Lehmann, J. 2000. Upper Albian ammonites from ODP Leg 171B off northern Florida. Palaeontology, 43:41-61. https://doi.org/10.1111/1475-4983.00118

Lerner, A.J., Lucas, S.G., and Lockley, M. 2017. First fossil horseshoe crab (Xiphosurida) from the Triassic of North America. Neues Jahrbuch für Geologie und PaläontologieAbhandlungen, 286:289-302. https://doi.org/10.1127/njgpa/2017/0702

Levin, P.A. and Angert, E.R. 2015. Small but mighty: cell size and bacteria. Cold Spring Harbor Perspectives in Biology, 7:a019216. https://doi.org/10.1101/cshperspect.a019216

Lustri, L., Laibl, L., and Bicknell, R.D.C. 2021. A revision of Prolimulus woodwardi Fritsch, 1899 with comparison to other paedomorphic belinurids. PeerJ, 9:e10980. https://doi.org/10.7717/peerj.10980

Meischner, K.-D. 1962. Neue Funde von Psammolimulus gottingensis (Merostomata, Xiphosura) aus dem Mittleren Buntsandstein von Göttingen. Paläontologische Zeitschrift, 36:185-193. https://doi.org/10.1007/bf02987900

Miklavc, P., Celarc, B., and Šmuc, A. 2016. Anisian Strelovec Formation in the Robanov kot, Savinja Alps (Northern Slovenia). Geologija, 59:23-34. https://doi.org/10.5474/geologija.2016.002

Pérez-Huerta, A., Coronado, I., and Hegna, T.A. 2018. Understanding biomineralization in the fossil record. Earth-Science Reviews, 179:95-122. https://doi.org/10.1016/j.earscirev.2018.02.015

Pickett, J.W. 1984. A new freshwater limuloid from the middle Triassic of New South Wales. Palaeontology, 27:609-621.

Raymond, P.E. 1944. Late Paleozoic xiphosurans. Bulletin of the Museum of Comparative Zoology, 94:475-508.

Richter, R. and Richter, E. 1929. Weinbergina opitzi n. g, n. sp., ein Schwertträger (Merost., Xiphos.) aus dem Devon (Rheinland). Senckenbergiana, 11:193-209. 
Riek, E.F. 1955. A new xiphosuran from the Triassic sediments at Brookvale, New South Wales. Records of the Australian Museum, 23:281-282. https://doi.org/10.3853/j.0067-1975.23.1955.637

Schiffbauer, J.D., Xiao, S., Cai, Y., Wallace, A.F., Hua, H., Hunter, J., Xu, H., Peng, Y., and Kaufman, A.J. 2014. A unifying model for Neoproterozoic-Palaeozoic exceptional fossil preservation through pyritization and carbonaceous compression. Nature Communications, 5:1-12. https://doi.org/10.1038/ncomms6754

Schmid, S.M., Bernoulli, D., Fügenschuh, B., Matenco, L., Schefer, S., Schuster, R., Tischler, M., and Ustaszewski, K. 2008. The Alpine-Carpathian-Dinaridic orogenic system: correlation and evolution of tectonic units. Swiss Journal of Geosciences, 101:139-183. https://doi.org/10.1007/s00015-008-1247-3

Shuster Jr., C.N. 1982. A pictorial review of the natural history and ecology of the horseshoe crab Limulus polyphemus, with reference to other Limulidae. Progress in Clinical and Biological Research, 81:1-52.

Stampfli, G.M., Borel, G.D., Marchant, R., and Mosar, J. 2002. Western Alps geological constraints on western Tethyan reconstructions. Journal of the Virtual Explorer, 8:77. https://doi.org/10.3809/jvirtex.2002.00057

Tetlie, O.E. and Van Roy, P. 2006. A reappraisal of Eurypterus dumonti Stainier, 1917 and its position within the Adelophthalmidae Tollerton, 1989. Bulletin de l'Institut Royal des Sciences Naturelles de Belgique, Sciences de la Terre, 76:79-90.

Tintori, A., Hitij, T., Jiang, D., Lombardo, C., and Sun, Z. 2014. Triassic actinopterygian fishes: the recovery after the end-Permian crisis. Integrative Zoology, 9:394-411. https://doi.org/10.1111/1749-4877.12077

Van Roy, P., Orr, P.J., Botting, J.P., Muir, L.A., Vinther, J., Lefebvre, B., El Hariri, K., and Briggs, D.E.G. 2010. Ordovician faunas of Burgess Shale type. Nature, 465:215-218. https://doi.org/10.1038/nature09038

Van Roy, P., Briggs, D.E.G., and Gaines, R.R. 2015. The Fezouata fossils of Morocco; an extraordinary record of marine life in the Early Ordovician. Journal of the Geological Society, 172:541-549. https://doi.org/10.1144/jgs2015-017

Vía Boada, L. 1987. Artropodos fosiles Triasicos de Alcover-Montral. II. Limulidos. Cuadernos Geología Ibérica, 11:281-294.

Vía, L. and De Villalta, J.F. 1966. Heterolimulus gadeai, nov. gen., nov. sp., représentant d'une nouvelle famille de Limulacés dans le Trias d'Espagne. Comtes Rendues Sommaire Séances Societé Géologique France, 8:57-59.

Vía, L., De Villalta, J.F., and Esteban Cerdá, M. 1977. Paleontología y Paleoecología de los yacimientos fosilíferos del Muschelkalk superior entre Alcover y Mont-Ral (Montañas de Prades, provincia de Tarragona). Journal of Iberian Geology, 4:247-258.

Žalohar, J. and Hitij, T. 2010. Depositional environment of the Strelovec Formation. Scopolia Supplement, 5:141-145.

Žalohar, J. and Hitij, T. 2013. Paleontološke raziskave v Anizijskih plasteh Strelovške formacije pod Vernerjem. Acta Triglavesia, 2:45. 